\title{
Antagonistic effects of exogenous Slit2 on VEGF-induced choroidal endothelial cell migration and tube formation
}

\author{
YANLING TANG and XIYUAN ZHOU
}

\begin{abstract}
Department of Ophthalmology, Second Affiliated Hospital of Chongqing Medical University, Chongqing 400010, P.R. China
\end{abstract}
Received March 5, 2018; Accepted October 26, 2018

DOI: $10.3892 / \mathrm{etm} .2019 .7235$

\begin{abstract}
Vascular endothelial growth factor (VEGF) is involved in the pathogenesis of choroidal neovascularization. The aim of the present study was to assess the effects of exogenous slit guidance ligand 2 (Slit2) on VEGF-induced choroidal endothelial cell (CEC) migration and tube formation. The protein and mRNA expression levels of Slit2, roundabout guidance receptor (Robo) 1 and Robo4 in CECs were evaluated by immunocy tochemistry and reverse transcription-polymerase chain reaction analyses, respectively. Western blot analysis was used to assess Robo4 protein levels in CECs exposed to increasing concentrations $(0,50,75,100,125$ and $150 \mathrm{ng} / \mathrm{ml})$ of exogenous Slit2. The effects of exogenous Slit2 $(125 \mathrm{ng} / \mathrm{ml})$ on VEGF-induced CEC migration and tube formation were also examined. CECs expressed Slit 2 and Robo4, but lacked Robol expression, at the mRNA and protein levels. Robo4 protein expression increased significantly following treatment with $50-150 \mathrm{ng} / \mathrm{ml}$ exogenous Slit2. No significant difference in Robo4 protein expression was observed in CECs treated with 125 and $150 \mathrm{ng} / \mathrm{ml}$ Slit2. VEGF-induced CEC migration and tube formation were significantly reduced following treatment with $125 \mathrm{ng} / \mathrm{ml}$ exogenous Slit2. In conclusion, these results indicate that Robo4 is expressed in CECs. In addition, exogenous Slit2 may regulate Robo4 expression and partially inhibit VEGF-induced CEC migration and tube formation.
\end{abstract}

\section{Introduction}

Choroidal neovascularization (CNV) is characterized by an abnormal growth of blood vessels between the neurosensory

Correspondence to: Dr Xiyuan Zhou, Department of Ophthalmology, Second Affiliated Hospital of Chongqing Medical University, 76 Lin Jiang Road, Yuzhong, Chongqing 400010, P.R. China

E-mail: t420663397@163.com

Abbreviations: VEGF, vascular endothelial growth factor; CEC, choroidal endothelial cell; $\mathrm{CNV}$, choroidal neovascularization; AMD, age-related macular degeneration

Key words: slit guidance ligand 2, roundabout guidance receptor 4, choroidal endothelial cell, vascular endothelial growth factor retina and the retinal pigment epithelium, and is a sight threatening condition most commonly associated with age-related macular degeneration (AMD) (1) and pathologic myopia (2). Despite the development of novel therapies for CNV, including laser photocoagulation, photodynamic therapy, pharmacotherapy and targeted gene therapy, this disorder remains a leading cause of severe central vision loss in individuals above the age of 50 years $(3,4)$.

Vascular endothelial growth factor (VEGF) is a chemotactic and angiogenic factor that is considered to be a major factor in the proliferation and migration of vascular endothelial cells (ECs) in AMD (5-7). CNV has been experimentally linked to the overexpression of VEGF, which promotes choroidal endothelial cell (CEC) proliferation and migration as well as capillary-like tube formation (8-10). CECs are located on the vascular layer of the eye, known as the choroidea or choroid coat. CECs have been reported in multiple previously published studies $(11,12)$, which have demonstrated that the inhibition of angiogenic signaling in CECs is able to ameliorate the $\mathrm{CNV}$ process. Current treatments for $\mathrm{CNV}$ primarily target VEGF-mediated processes (13). While VEGF is a potent inducer of angiogenesis, understanding the roles of additional angiogenic stimuli would be invaluable for the development of novel CNV therapies (14).

The Slit guidance ligand family of proteins (Slit1, Slit2 and Slit3) are secreted extracellular matrix proteins involved in neural development, and participate in additional physiological and pathological processes, including angiogenesis, inflammation and cancer (15-17). Slit2 guides axon growth and controls neurocyte migration (18). The Slit proteins interact with roundabout guidance (Robo) receptors (Robo1, Robo2, Robo3 and Robo4), to mediate chemorepulsion of olfactory bulb explants in vitro (19). The Robo family of proteins are primarily expressed in the nervous system; however, they are also detectable in other tissues, including vascular, renal and tumor tissues (20). In addition, Slit2 has been demonstrated to influence tumor angiogenesis, growth and metastasis (21-23) while inhibiting retinal neovascularization $(24,25)$.

Previous studies have demonstrated that Slit2 may positively or negatively regulate VEGF-directed permeability depending on whether it binds to Robo1 or Robo4 receptors, respectively $(26,27)$. These and the results of additional studies suggest that Slit2-mediated responses may be determined by the tissue-specific expression of Robol and Robo4 receptors in ECs $(28,29)$. For instance, Slit2 inhibits hantavirus-induced 
enhancement of pulmonary EC permeability via a mechanism involving Robo4 (30); a vascular-specific receptor expressed in ECs (31). In addition, Robo4 mediates Slit2-mediated alternations in cell migration and tube formation in ECs. A previous study demonstrated that Robo4 activation by Slit2 inhibits VEGF-induced EC migration, tube formation and permeability in vitro, as well as VEGF-stimulated vascular leakage in vivo, by inhibiting the activation of Src family kinases (24). Two additional reports revealed that Slit2 interacts with Robo4 to inhibit VEGF- and basic fibroblast growth factor-induced CE migration $(32,33)$. Notably, Slit2 has also been implicated in the migration of vascular smooth muscle cells (34).

Despite considerable evidence supporting the important role of Slit2 in mediating the migration of various types of ECs, there is limited information regarding the effects of Slit2 on CEC migration and tube formation. The authors of the present study hypothesized that Slit2 may modulate CEC migration and tube formation induced by VEGF. To test this hypothesis, the present study assessed the effects of exogenous Slit2 on VEGF-induced CEC migration and angiogenesis.

\section{Materials and methods}

Cell culture and grouping. All cell culture reagents were purchased from Sigma-Aldrich; Merck KGaA (Darmstadt, Germany) unless otherwise specified. Human CECs (cat. no. CP-H092) were purchased from Procell Life Science \& Technology Co., Ltd., (Wuhan, China) and cultured in complete medium consisting of M199 medium supplemented with $10 \%$ fetal bovine serum, $100 \mu \mathrm{g} / \mathrm{ml}$ endothelial cell growth supplement, $1,000 \mu \mathrm{g} / \mathrm{ml}$ heparin sulfate (Gibco; Thermo Fisher Scientific, Inc., Waltham, MA, USA), 100 U/ml penicillin and $100 \mu \mathrm{g} / \mathrm{ml}$ streptomycin. Cells were grown in a humidified atmosphere with $5 \% \mathrm{CO}_{2}$ at $37^{\circ} \mathrm{C}$.

CECs were subjected to reverse transcription-polymerase chain reaction (RT-PCR) and immunocytochemistry analyses to detect the expression of specific genes and proteins, respectively. The cells were cultured in 6-well plates at a density of $5 \times 10^{4}$ cells $/ \mathrm{ml}$ and exposed to $0,50,75,100,125$ and $150 \mathrm{ng} / \mathrm{ml}$ recombinant human Slit2-N protein (PeproTech, Inc., Rocky Hill, NJ, USA) for $8 \mathrm{~h}$ before they were harvested for analysis.

For cell migration and tube formation assays, cells were divided into the following 4 groups: Non-treatment control, cells cultured in M199 medium only; Slit2, cells cultured in M199 medium containing $125 \mathrm{ng} / \mathrm{ml}$ Slit2-N; VEGF, cells cultured in M199 medium containing $20 \mathrm{ng} / \mathrm{ml}$ VEGF (PeproTech, Inc.); and Slit2+VEGF, cells cultured in M199 medium containing $125 \mathrm{ng} / \mathrm{ml}$ Slit2-N plus $20 \mathrm{ng} / \mathrm{ml}$ VEGF (35).

Cell migration assay. The cell migration assay was performed using 24-well plates containing Transwell inserts with $8-\mu \mathrm{m}$ pore polyethylene terephthalate (PET) membranes separating the inner and outer chambers. CECs were seeded onto the insert at $1 \times 10^{4}$ cells $/ \mathrm{ml}$ and the appropriate medium was added to the wells according to each group. Following incubation for $8 \mathrm{~h}$, cells on the PET membrane were fixed with $4 \%$ paraformaldehyde for $30 \mathrm{~min}$ at room temperature, while any non-migrating cells on the inner side of the membrane were removed gently with a cotton swab. Cells that had migrated through the pores onto the lower surface of the membrane were stained with $0.01 \%$ crystal violet for $20 \mathrm{~min}$ at room temperature, counted and photographed under an inverted microscope (BX51; Olympus Corporation, Tokyo, Japan).

Tube formation assay. Matrigel was diluted in cold serum-free cell culture medium at a 1:1 ratio, and used to coat 96-well culture dishes for $2 \mathrm{~h}$ at $37^{\circ} \mathrm{C}$. CECs were then resuspended in the appropriate culture medium according to each group and plated at $1 \times 10^{4}$ cells $/ \mathrm{ml}$. Following $8 \mathrm{~h}$, tubular structures were counted and photographed under an inverted microscope (Olympus Corporation). For each group, 5 random fields were selected to calculate the average number and standard deviation of tube formations.

Immunocytochemistry. CECs mounted onto slides were treated and fixed with $4 \%$ paraformaldehyde for $15 \mathrm{~min}$ at room temperature. The cells were then washed with PBS and incubated with $0.5 \%$ Triton X-100/PBS for $20 \mathrm{~min}$ at $4^{\circ} \mathrm{C}$. Cells were blocked with $10 \%$ goat serum (cat. no. ab7481; Abcam, Cambridge, UK) for $20 \mathrm{~min}$ at room temperature. Factor VIII-related antigen, Slit2, Robo1 and Robo4 proteins were then detected. To do this, CECs were incubated with rabbit polyclonal anti-Factor VIII-related antigen (dilution, 1:50; cat. no. TA325456; OriGene Technologies, Inc., Rockville, MD, USA), and anti-human Slit2 (cat. no. sc-514499), Robo1 (cat. no. sc-293444) and Robo4 (cat. no. sc-166872) (all diluted at 1:1,000 and purchased from Santa Cruz Biotechnology, Inc., Dallas, TX, USA) primary antibodies at $4^{\circ} \mathrm{C}$ overnight. Cells were then washed with PBS and incubated with horseradish peroxidase (HRP)-conjugated goat anti-rabbit $\mathrm{IgG}$ secondary antibodies (dilution, 1:200; cat. no. ab6721; Abcam) at $37^{\circ} \mathrm{C}$ for $30 \mathrm{~min}$. A 3,3'-diaminobenzidine substrate kit (Sangon Biotech, Co., Ltd., Shanghai, China) was used for chromogenic detection. The nuclei were stained with $0.5 \%$ hematoxylin for $3 \mathrm{~min}$ at room temperature. The results were observed and photographed under an inverted microscope (Olympus Corporation).

Western blot analysis. Cells were treated with protein lysis solution (Beyotime Institute of Biotechnology, Shanghai, China) containing $10 \mathrm{mM}$ phenylmethylsulfonyl fluoride. Protein concentrations were determined using the bicinchoninic acid protein assay (Thermo Fisher Scientific, Inc.). An equal quantity $(30 \mu \mathrm{g})$ of protein for each sample was loaded and resolved by SDS-PAGE using a $6 \%$ gel, followed by transfer onto polyvinylidene difluoride membranes (Merck KGaA). The membranes were then incubated with primary antibodies against Robo4 (dilution, 1:1,000; cat. no. sc-166872; Santa Cruz Biotechnology, Inc.) and GAPDH (dilution, 1:1,000; cat. no. ab8245; Abcam) at $4^{\circ} \mathrm{C}$ overnight, followed by incubation with HRP-conjugated goat anti-rabbit $\mathrm{IgG}$ antibodies (dilution, 1:1,000; cat. no. ab6721; Abcam) for $1 \mathrm{~h}$ at room temperature. Protein bands were visualized using an enhanced chemiluminescence kit (Thermo Fisher Scientific, Inc.), and protein expression was semi-quantified using Quantity One software 4.6 (Bio-Rad Laboratories, Inc., Hercules, CA, USA).

RT-PCR. Total RNA from CECs was isolated using TRIzol reagent (Thermo Fisher Scientific, Inc.) according to the 
manufacturer's protocol. Reverse-transcription was performed using the Takara PrimeScript RT Reagent kit (Takara Bio, Inc., Otsu, Japan). The mRNA expression levels of Slit2, Robo1, Robo4 and $\beta$-actin were assessed via PCR amplification of target cDNA sequences using TaKaRa Z-Taq ${ }^{\mathrm{TM}}$ DNA Polymerase (Takara Bio, Inc.). The thermocycling conditions were as follows: $94^{\circ} \mathrm{C}$ for $5 \mathrm{~min}$ followed by 30 cycles of $94^{\circ} \mathrm{C}$ for $30 \mathrm{sec}, 60^{\circ} \mathrm{C}$ for $30 \mathrm{sec}, 72^{\circ} \mathrm{C}$ for $60 \mathrm{sec}$, and maintenance at $72^{\circ} \mathrm{C}$ for $10 \mathrm{~min}$. PCR products were resolved by $2 \%$ agarose gel electrophoresis, and visualized by staining with ethidium bromide. The sequences of primers used for RT-PCR are presented in Table I.

Statistical analysis. Samples were run in triplicate and all experiments were repeated three times. The data are presented as the mean \pm standard deviation and analyzed using SPSS 17.0 software (SPSS Inc., Chicago, IL, USA). Comparisons among groups were analyzed by one-way analysis of variance followed by the least significant difference post hoc test. $\mathrm{P}<0.05$ was considered to indicate a statistically significant difference.

\section{Results}

CECs form confluent monolayers and largely express Factor VIII-related antigen. CECs were observed to form confluent monolayers with a cobblestone appearance under a microscope. Cells were confirmed to be vascular ECs by positive immunocytochemistry staining for Factor VIII-related antigen (36) in more than $95 \%$ of cells (Fig. 1).

CECs express Slit2 and Robo4, but not Robol. Robo1 is expressed in retinal pigment epithelial cells and vascular endothelial cells (37); however, its expression profile in CECs is currently unknown. RT-PCR detected Slit2 and Robo4 mRNA expression, but not Robo1, in CECs (Fig. 2A). Consistent with these results, immunocytochemistry analysis detected Slit2 and Robo4, but not Robo1, protein expression in CECs (Fig. 2B-F).

Exogenous Slit2 upregulates Robo4 protein expression in a concentration-dependent manner. Treatment with $0,50,75,100,125$ and $150 \mathrm{ng} / \mathrm{ml}$ exogenous Slit2 was associated with a concentration-dependent increase in Robo4 protein levels in CECs (Fig. 3). Robo4 protein expression levels were significantly higher in CECs treated with $125 \mathrm{ng} / \mathrm{ml}$ Slit2 when compared with cells exposed to lower concentrations $(\mathrm{P}<0.05$; Fig. 3B). However, no significant difference in Robo4 protein expression was observed between the 125 and $150 \mathrm{ng} / \mathrm{ml}$ Slit2-treated groups. For this reason, a concentration of $125 \mathrm{ng} / \mathrm{ml}$ Slit2 was selected for subsequent cell migration and tube formation assays.

Slit2 inhibits VEGF-induced CEC migration. Using Transwell migration assays, exogenous VEGF (10 ng/ml) was observed to enhance the migration of CECs when compared with untreated controls (Fig. 4). Despite the observation that Slit2 treatment $(125 \mathrm{ng} / \mathrm{ml})$ alone demonstrated no significant effect on CEC migration when compared with the control group, it significantly inhibited VEGF-induced CEC migration ( $\mathrm{P}<0.05$; Fig. 4).
Table I. Sequences for RT-PCR and the sizes of PCR product sizes.

\begin{tabular}{llc}
\hline Primer & \multicolumn{1}{c}{ Sequence (5'-3') } & Size (bp) \\
\hline Slit2 & & \\
Forward & TGGCTATCAGGGAGAAAAGTGTG & 176 \\
Reverse & CCGCGATATGGTCTTTGTCAC & \\
Robo1 & & \\
Forward & CAGCACCAGCCCGACAGGAG & 124 \\
Reverse & GCGCATCCGTATCCATATCTGAG & \\
Robo4 & & \\
Forward & CCACCCATATGCCAGGCTCCTAC & 226 \\
Reverse & CCCAGAAGCAGCAGCCAGAGTG & \\
$\beta$-actin & & 188 \\
Forward & GTGATCTCCTTCTGCATCCTGT & \\
Reverse & CCACGAAACTACCTTCAACTCC & \\
\hline
\end{tabular}

Slit2, slit guidance ligand 2; Robo1, roundabout guidance receptor 1; Robo4, roundabout guidance receptor 4; bp, base pair.

Slit2 inhibits VEGF-induced CEC tube formation. As presented in Fig. 5, CECs migrated gradually and formed connections to produce simple tubular structures of differing shapes and sizes. Treatment with VEGF (10 ng/ml) was associated with an increase in tube formation when compared with controls (Fig. 5). Treatment with $125 \mathrm{ng} / \mathrm{ml}$ Slit2 alone demonstrated no significant effect on tube formation when compared with controls (Fig. 5); however, Slit2 (125 ng/ml) significantly attenuated VEGF-induced tube formation ( $\mathrm{P}<0.05$; Fig. 5).

\section{Discussion}

A noteworthy observation of the current study was that Slit2 and Robo4 but not Robo1, were expressed in human CECs. In addition, Robo4 was upregulated by exogenous Slit 2 treatment $(0-125 \mathrm{ng} / \mathrm{ml})$ in a concentration-dependent manner. Importantly, VEGF-induced CEC migration and tube formation was inhibited by exogenous Slit 2 treatment. Combined with the results of previously published studies (28-34), these results support the hypothesis that Slit2 may interact with Robo4 to inhibit VEGF-induced CEC migration and tube formation, and subsequent angiogenesis. However, further studies are necessary to confirm this hypothesis and determine whether the Slit2/Robo4 signaling pathway may present a therapeutic target for the development of novel CNV therapies.

The present study utilized RT-PCR and immunocytochemistry analyses and determined that Slit2 and Robo4 mRNA and protein were expressed in human CECs, whereas Robol was not. These findings corroborate previous studies demonstrating that Robo4, but not Robo1, is expressed in microvascular ECs (38) and pulmonary microvascular ECs (30). EC-specific expression of Robo4 is well established (39). However, in contrast to the results of previous studies, Robol expression was reportedly expressed in vascular ECs from rabbits with experimental proliferative vitreoretinopathy (37), in retinal and choroidal tissue samples from mice with experimental 

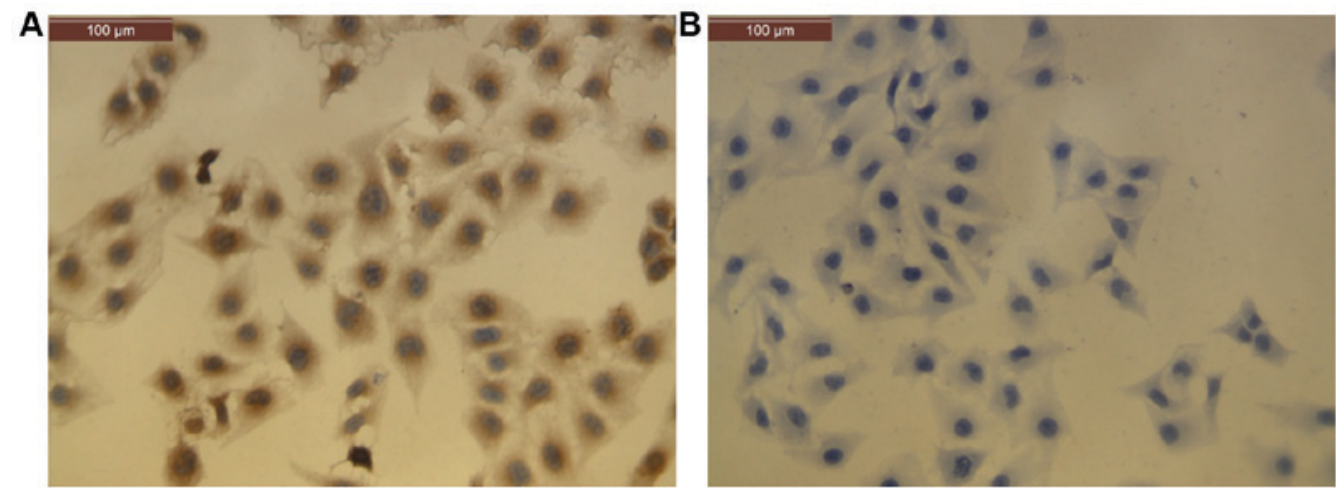

Figure 1. Culture and characterization of human CECs by immunocytochemistry staining. (A) Positive staining for Factor VIII-related antigen was observed in $>95 \%$ of cultured CECs. (B) Negative control (immunocytochemistry performed without a primary antibody). Scale bar, $100 \mu \mathrm{m}$. CECs, choroidal endothelial cells

A

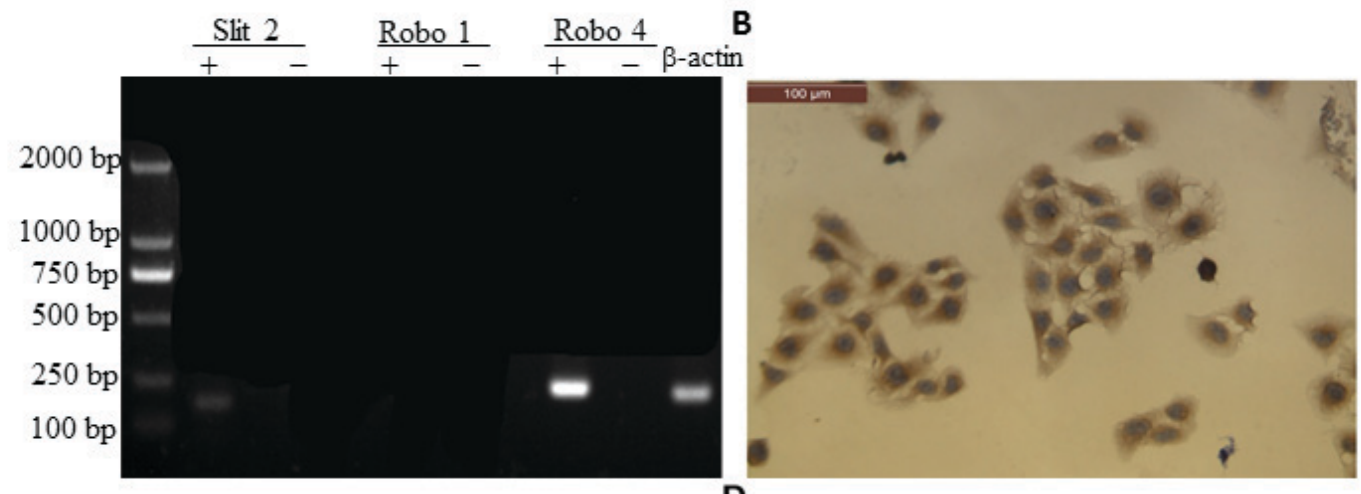

C

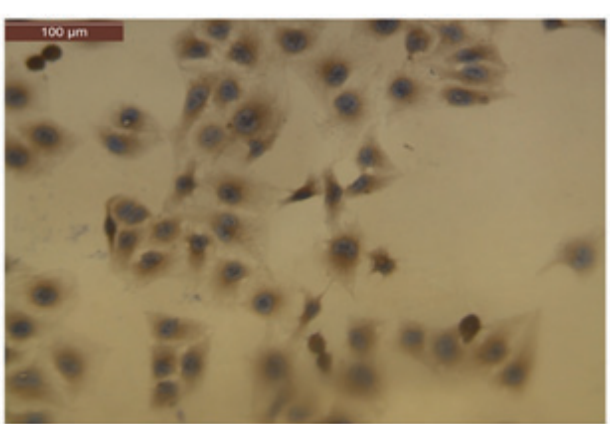

D

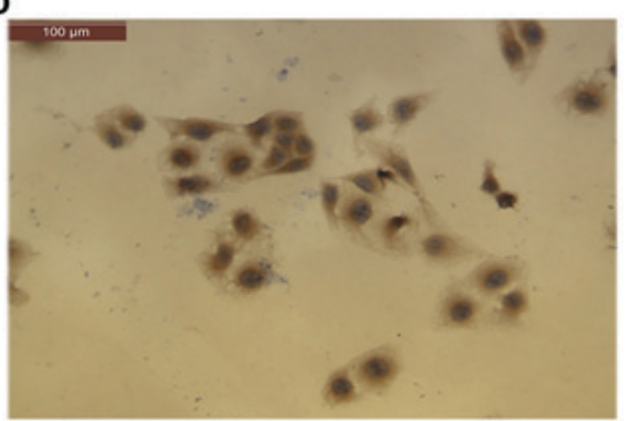

Robo4

Factor VIII

E

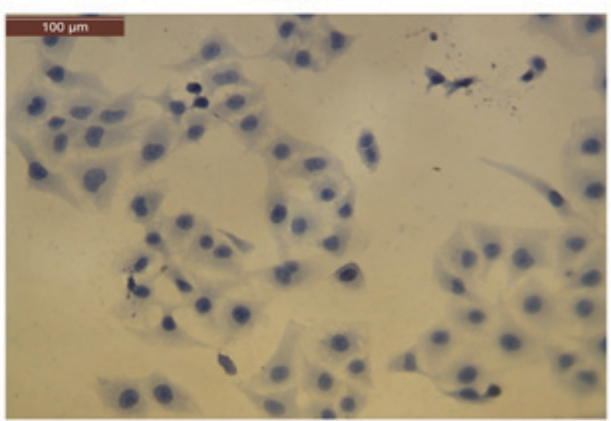

Robo1

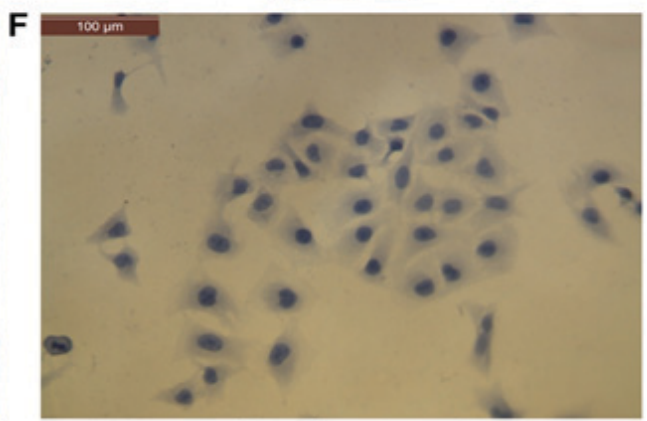

Negative control

Figure 2. Detection of Slit2, Robol and Robo4 mRNA and protein expression in human CECs. (A) RT-PCR analysis yielded expected products at 176 bp and 226 bp for Slit2 and Robo4, respectively; no product for Robo1 was detected. '+' indicates the addition of target-specific primers to the reaction and '-' indicates the addition of no primers. (B-E) Immunocytochemistry analysis demonstrated positive staining for (B) Slit2, (C) Robo4 proteins and (D) Factor VIII-related antigen, but not (E) Robol. (F) Negative control (immunocytochemistry performed without a primary antibody). Scale bar, $100 \mu \mathrm{m}$. Slit2, slit guidance ligand 2; Robo, roundabout guidance receptor; CECs, choroidal endothelial cells.

laser-induced CNV (40), in retinal tissue specimens from mice with experimental retinal neovascularization (41) and in human umbilical vein ECs (HUVECs) $(30,40)$. It is therefore possible that Robol expression in ECs is species-specific, as 
A

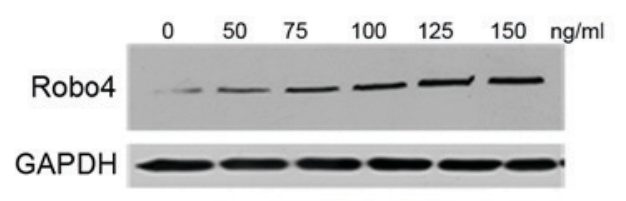

$\mathrm{B}$

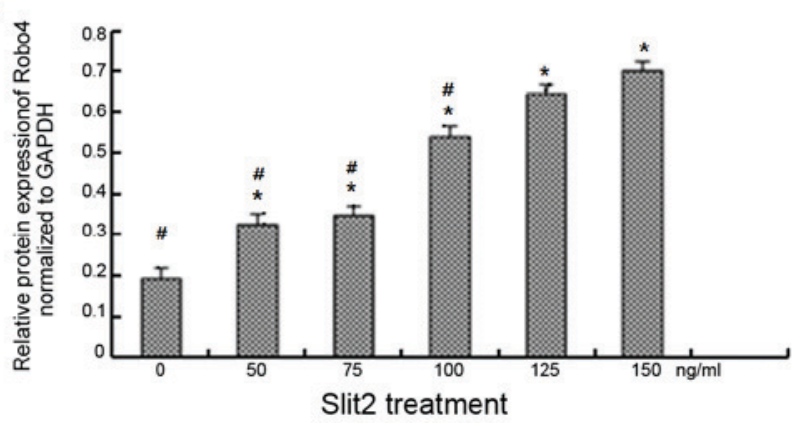

Figure 3. Exogenous Slit2 increases Robo4 protein expression in human CECs. (A and B) Human CECs were exposed to Slit2 protein of various concentrations for $8 \mathrm{~h}$, and Robo4 protein expression was quantified by western blot analysis. (A) Representative western blotting images of Robo4 protein expression upon Slit2 treatment. GAPDH was used as the loading control. (B) Semi-quantitative analysis of the western blotting results. "P<0.05 vs. the $0 \mathrm{ng} / \mathrm{ml}$ group and ${ }^{\text {\#}} \mathrm{P}<0.05$ vs. the $125 \mathrm{ng} / \mathrm{ml}$ group. Samples were run in triplicate and experiments were performed three times. Slit2, slit guidance ligand 2; Robo, roundabout guidance receptor; CECs, choroidal endothelial cells.

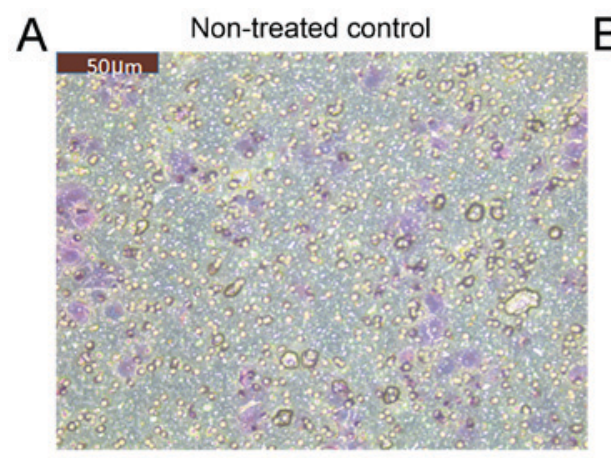

B $\quad 125 \mathrm{ng} / \mathrm{ml}$ Slit2

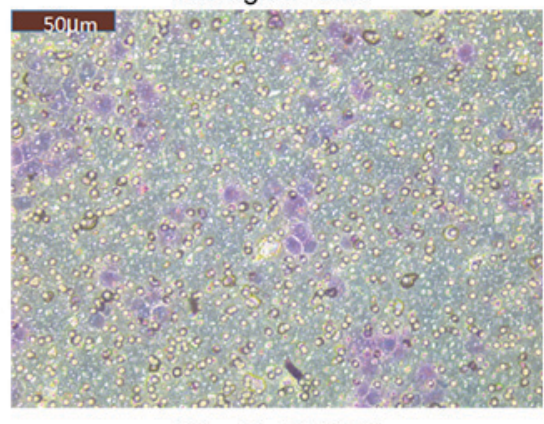

D

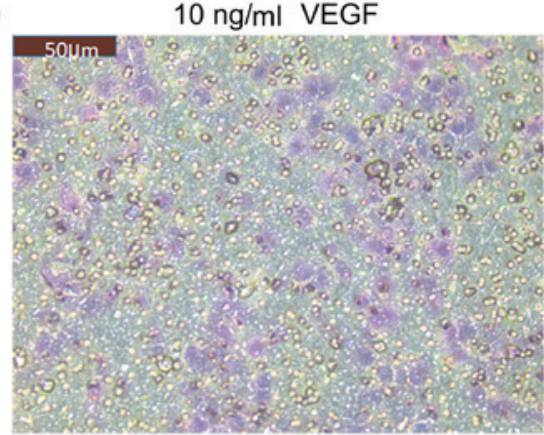

E
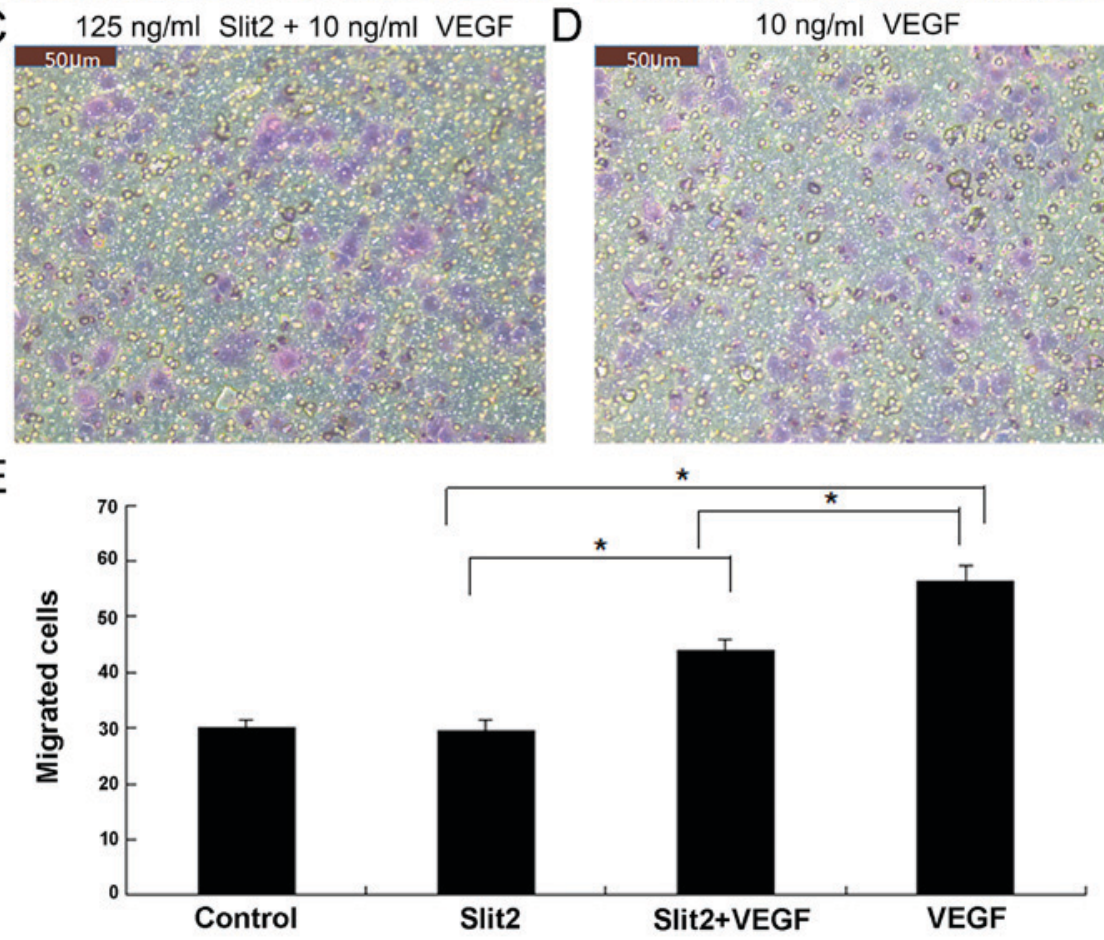

Figure 4. Slit2 attenuates VEGF-induced CEC migration. (A-E) Human CECs were treated with Slit2 and/or VEGF for 8 h. Representative photographs present the migrated cells stained with crystal violet in the (A) non-treatment control, (B) $125 \mathrm{ng} / \mathrm{ml} \mathrm{Slit2}$, (C) $125 \mathrm{ng} / \mathrm{ml} \mathrm{Slit} 2+10 \mathrm{ng} / \mathrm{ml} \mathrm{VEGF} \mathrm{and}$ (D) $10 \mathrm{ng} / \mathrm{ml}$ VEGF treatment groups. (E) Quantitative analysis of the number of migrated CECs in each experimental group. Samples were run in triplicate and experiments were performed three times. Scale bar, $50 \mu \mathrm{m}{ }^{*} \mathrm{P}<0.05$, as indicated. Slit2, slit guidance ligand 2; VEGF, vascular endothelial growth factor; CECs, choroidal endothelial cells.

the majority of studies that have demonstrated positive expression of Robol in ECs used mouse or rabbit models. In addition, it is also possible that Robol expression may be enhanced under pathological conditions such as $\mathrm{CNV}$ and proliferative 

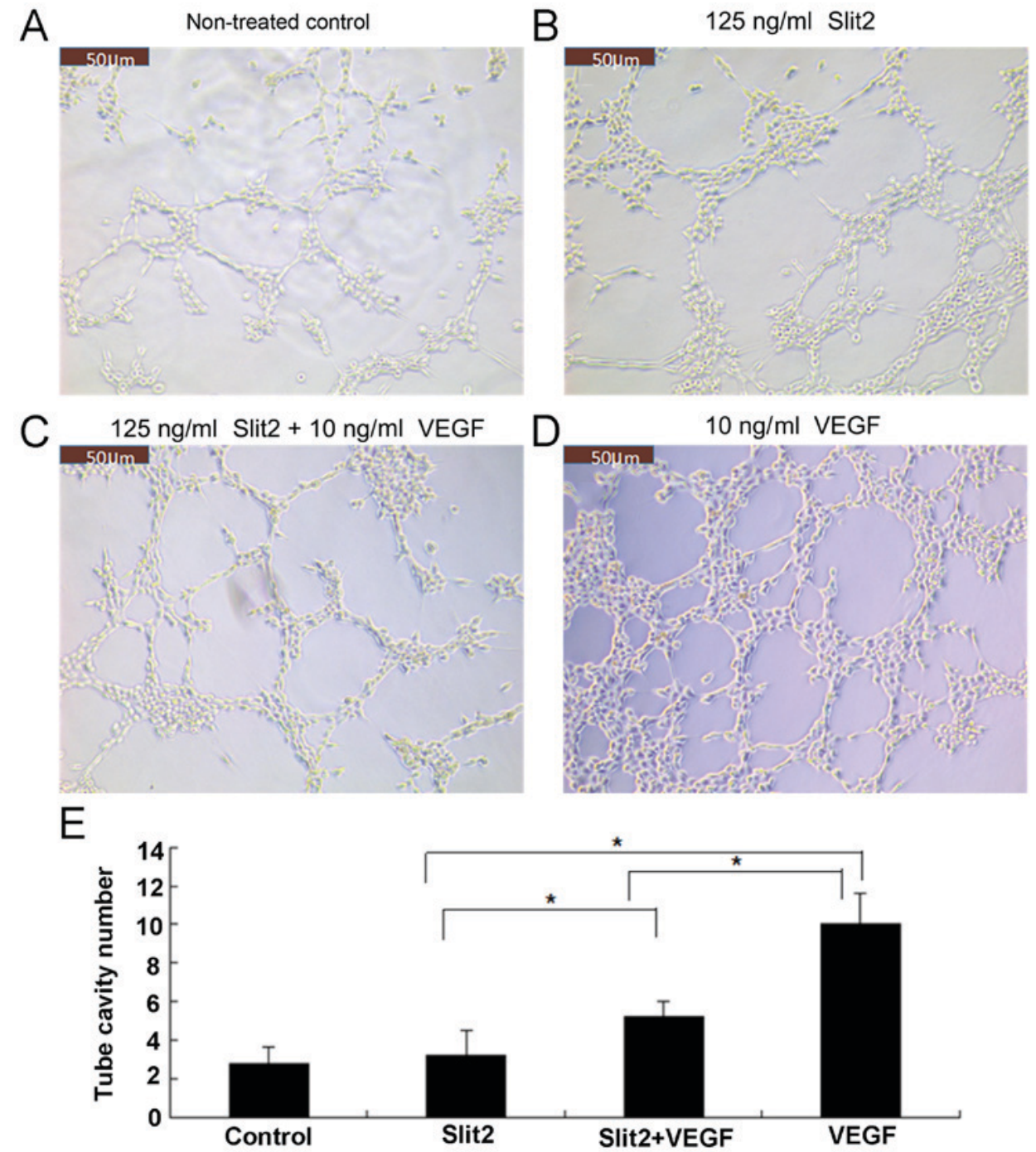

Figure 5. Slit2 attenuates VEGF-induced CEC tube formation. (A-E) Human CECs were treated with Slit2 and/or VEGF for 8 h. Representative photographs present the tube formation in the (A) non-treated control, (B) $125 \mathrm{ng} / \mathrm{ml}$ Slit2, (C) $125 \mathrm{ng} / \mathrm{ml} \mathrm{Slit} 2+10 \mathrm{ng} / \mathrm{ml} \mathrm{VEGF}$ treatment and (D) $10 \mathrm{ng} / \mathrm{ml}$ VEGF treatment groups. (E) Quantitative analysis of the number of tube cavities formed. Samples were run in triplicate and experiments were performed three times. Scale bar, $50 \mu \mathrm{m} .{ }^{*} \mathrm{P}<0.05$, as indicated. Slit2, slit guidance ligand 2; VEGF, vascular endothelial growth factor; CECs, choroidal endothelial cells.

vitreoretinopathy. Therefore, although Robo4 may be the predominant isoform expressed in CECs, additional studies are required to establish whether Robol may also be upregulated and whether this may contribute to the pathogenesis of CNV.

The results of the present study demonstrated that Robo4 was upregulated by Slit2 treatment in a concentration-dependent manner. To the best of the authors' knowledge, this is the first study to demonstrate that Robo4 protein levels in human CECs may be altered by Slit2. However, these results are consistent with a previously published similar study demonstrating that Slit2 overexpression in HUVECs was associated with upregulation of Robo1 expression (40). As Robo4 may serve a role in mediating the effects of Slit2 in attenuating VEGF-induced angiogenesis by CECs, Slit2-mediated upregulation of Robo4 would be predicted to further enhance the potentially beneficial effects of Slit2 against CNV.

In the current study, VEGF-induced CEC migration and tube formation were significantly attenuated by co-treatment with Slit2. These results are consistent with the study from Park et al (38), which reported that Slit2 inhibits VEGF-induced migration in primary human ECs. Multiple additional studies have demonstrated that Slit2 and/or Robo4 inhibit EC migration and/or tube formation induced by $\operatorname{VEGF}(31,32,42,43)$. Previous reports have also revealed that Robol affects EC migration (29,44-46). However, the lack of Robol expression observed in human CECs in the present study suggests that Robo4 may be involved in the mechanism by which Slit2 attenuates VEGF-induced CEC migration.

The current study did not investigate the potential mechanisms by which the Slit2/Robo4 signaling pathway may attenuate VEGF-induced CEC migration and tube formation. However, previous investigations have yielded some insight into these potential mechanisms. EC migration in response to VEGF requires activation of the protein kinase B (Akt)/endothelial nitric oxide synthase signaling pathway, as well as the extracellular signal-regulated protein kinase 1/2 (Erk1/2) signaling pathway (35). VEGF receptor (VEGFR)-2 has also been hypothesized to activate the small guanosine 5'-triphosphatase (GTPase), Rac1, via Src-dependent phosphorylation of Vav2; a guanine nucleotide-exchange factor $(47,48)$. 
Regarding how Slit2 may interact with these signaling pathways, Slit2-N reportedly led to VEGFR-3 internalization, thereby inhibiting PI3K/Akt signaling pathway activation by VEGF (43). Meanwhile, Cai et al (31) provided evidence to suggest that Robo4 inhibits VEGFR-mediated activation of PI3K/Akt and FAK signaling pathways. In addition, Slit2-N attenuates platelet-derived growth factor-mediated activation of Rac1 (34). Notably, Robo4-induced inhibition of EC migration is partly mediated by the Ras/Raf/Mek/Erk signaling pathway (32). Moreover, Robo4 mediates the effects of Slit2 by forming a complex with paxillin, which inhibits the activation of the small GTPase, ADP ribosylation factor 6, and consequently inhibits Rac (25). Therefore, it is possible that inhibition of VEGF-induced CEC migration by Slit2/Robo4 signaling may involve Rac1, although further studies are required to confirm this.

In conclusion, the results of the current study demonstrate that Slit2 inhibits VEGF-induced CEC migration and tube formation. Further studies are required to determine whether Robo4 is involved in these Slit2-mediated effects and to identify the underlying mechanisms. Our exploring on Slit2/Robo4 signaling related mechanisms in reducing human CEC angiogenesis would facilitate the development of novel therapies for the treatment of CNV.

\section{Acknowledgements}

Not applicable.

\section{Funding}

The current study was funded by the Natural Science Foundation of China (grant no. 81170858).

\section{Availability of data and materials}

Data are available on request.

\section{Authors' contributions}

YT performed the experiments, participated in data collection and drafted the manuscript. XZ designed the experiments, revised the manuscript and supervised the current study.

\section{Ethics approval and consent to participate}

Not applicable.

\section{Patient consent for publication}

Not applicable.

\section{Competing interests}

The authors declare that they have no competing interests.

\section{References}

1. Shao J, Choudhary MM and Schachat AP: Neovascular age-related macular degeneration. Dev Ophthalmol 55: 125-136, 2016.
2. Wong TY, Ferreira A, Hughes R, Carter G and Mitchell P: Epidemiology and disease burden of pathologic myopia and myopic choroidal neovascularization: An evidence-based systematic review. Am J Ophthalmol 157: 9-25.e12, 2014.

3. Blinder KJ, Bradley S, Bressler NM, Bressler SB, Donati G, Hao Y, Ma C, Menchini U, Miller J, Potter MJ, et al: Effect of lesion size, visual acuity, and lesion composition on visual acuity change with and without verteporfin therapy for choroidal neovascularization secondary to age-related macular degeneration: TAP and VIP report no. 1. Am J Ophthalmol 136: 407-418, 2003.

4. D'Amico DJ, Goldberg MF, Hudson H, Jerdan JA, Krueger S, Luna S, Robertson SM, Russell S, Singerman L, Slakter JS, et al: Anecortave acetate as monotherapy for the treatment of subfoveal lesions in patients with exudative age-related macular degeneration (AMD): Interim (month 6) analysis of clinical safety and efficacy. Retina 23: 14-23, 2003.

5. Sakamoto T, Ishibashi T, Kimura H, Yoshikawa H, Spee C, Harris MS, Hinton DR and Ryan SJ: Effect of tecogalan sodium on angiogenesis in vitro by choroidal endothelial cells. Invest Ophthalmol Vis Sci 36: 1076-1083, 1995.

6. Ohno-Matsui K, Morita I, Tombran-Tink J, Mrazek D, Onodera M, Uetama T, Hayano M, Murota SI and Mochizuki M: Novel mechanism for age-related macular degeneration: An equilibrium shift between the angiogenesis factors VEGF and PEDF. J Cell Physiol 189: 323-333, 2001.

7. Klagsbrun $M$ and D'Amore PA: Regulators of angiogenesis. Annu Rev Physiol 53: 217-239, 1991.

8. Frank RN: Growth factors in age-related macular degeneration: Pathogenic and therapeutic implications. Ophthalmic Res 29: 341-353, 1997.

9. Schwesinger C, Yee C, Rohan RM, Joussen AM, Fernandez A, Meyer TN, Poulaki V, Ma JJ, Redmond TM, Liu S, et al: Intrachoroidal neovascularization in transgenic mice overexpressing vascular endothelial growth factor in the retinal pigment epithelium. Am J Pathol 158: 1161-1172, 2001.

10. Ferrara N: Vascular endothelial growth factor and age-related macular degeneration: From basic science to therapy. Nat Med 16: 1107-1111, 2010.

11. Yan Z, Shi H, Zhu R, Li L, Qin B, Kang L, Chen H and Guan H: Inhibition of YAP ameliorates choroidal neovascularization via inhibiting endothelial cell proliferation. Mol Vis 24: 83-93, 2018.

12. Gunda V, Verma RK and Sudhakar YA: Inhibition of elastin peptide-mediated angiogenic signaling mechanism(s) in choroidal endothelial cells by the $\alpha 6$ (IV)NC1 collagen fragment. Invest Ophthalmol Vis Sci 54: 7828-35, 2013.

13. Stone EM: A very effective treatment for neovascular macular degeneration. N Engl J Med 355: 1493-1495, 2006.

14. van Wijngaarden P, Coster DJ and Williams KA: Inhibitors of ocular neovascularization: Promises and potential problems. JAMA 293: 1509-1513, 2005.

15. Howitt JA, Clout NJ and Hohenester E: Binding site for Robo receptors revealed by dissection of the leucine-rich repeat region of Slit. EMBO J 23: 4406-4412, 2004.

16. Morlot C, Thielens NM, Ravelli RB, Hemrika W, Romijn RA, Gros P, Cusack S and McCarthy AA: Structural insights into the Slit-Robo complex. Proc Natl Acad Sci USA 104: 14923-14928, 2007.

17. Fujiwara M, Ghazizadeh $\mathrm{M}$ and Kawanami O: Potential role of the Slit/Robo signal pathway in angiogenesis. Vasc Med 11: 115-121, 2006.

18. Li HS, Chen JH, Wu W, Fagaly T, Zhou L, Yuan W, Dupuis S, Jiang ZH, Nash W, Gick C, et al: Vertebrate slit, a secreted ligand for the transmembrane protein roundabout, is a repellent for olfactory bulb axons. Cell 96: 807-818, 1999.

19. Patel K, Nash JA, Itoh A, Liu Z, Sundaresan V and Pini A: Slit proteins are not dominant chemorepellents for olfactory tract and spinal motor axons. Development 128: 5031-5037, 2001.

20. Hohenester E: Structural insight into Slit-Robo signalling. Biochem Soc Trans 36: 251-256, 2008.

21. Wang B, Xiao Y, Ding BB, Zhang N, Yuan X, Gui L, Qian KX, Duan S, Chen Z, Rao Y and Geng JG: Induction of tumor angiogenesis by Slit-Robo signaling and inhibition of cancer growth by blocking Robo activity. Cancer Cell 4: 19-29, 2003.

22. Wang LJ, Zhao Y, Han B, Ma YG, Zhang J, Yang DM, Mao JW, Tang FT, Li WD, Yang Y, et al: Targeting Slit-Roundabout signaling inhibits tumor angiogenesis in chemical-induced squamous cell carcinogenesis. Cancer Sci 99: 510-517, 2008. 
23. Yang XM, Han HX, Sui F, Dai YM, Chen M and Geng JG: Slit-Robo signaling mediates lymphangiogenesis and promotes tumor lymphatic metastasis. Biochem Biophys Res Commun 396: 571-577, 2010.

24. Jones CA, London NR, Chen H, Park KW, Sauvaget D, Stockton RA, Wythe JD, Suh W, Larrieu-Lahargue F, Mukouyama YS, et al: Robo4 stabilizes the vascular network by inhibiting pathologic angiogenesis and endothelial hyperpermeability. Nat Med 14: 448-453, 2008

25. Jones CA, Nishiya N, London NR, Zhu W, Sorensen LK, Chan AC, Lim CJ, Chen H, Zhang Q, Schultz PG, et al: Slit2-Robo4 signalling promotes vascular stability by blocking Arf6 activity. Nat Cell Biol 11: 1325-1331, 2009.

26. Acevedo LM, Weis SM and Cheresh DA: Robo4 counteracts VEGF signaling. Nat Med 14: 372-373, 2008.

27. Koch AW, Mathivet T, Larrivée B, Tong RK, Kowalski J, Pibouin-Fragner L, Bouvrée K, Stawicki S, Nicholes K, Rathore N, et al: Robo4 maintains vessel integrity and inhibits angiogenesis by interacting with UNC5B. Dev Cell 20: 33-46, 2011.

28. Dickinson RE and Duncan WC: The SLIT-ROBO pathway: A regulator of cell function with implications for the reproductive system. Reproduction 139: 697-704, 2010.

29. Sheldon H, Andre M, Legg JA, Heal P, Herbert JM, Sainson R, Sharma AS, Kitajewski JK, Heath VL and Bicknell R: Active involvement of Robo1 and Robo4 in filopodia formation and endothelial cell motility mediated via WASP and other actin nucleation-promoting factors. FASEB J 23: 513-522, 2009.

30. Gorbunova EE, Gavrilovskaya IN and Mackow ER: Slit2-Robo4 receptor responses inhibit ANDV directed permeability of human lung microvascular endothelial cells. Antiviral Res 99: 108-112, 2013

31. Cai H, Xue Y, Li Z, Hu Y, Wang Z, Liu W, Li Z and Liu Y: Roundabout4 suppresses glioma-induced endothelial cell proliferation, migration and tube formation in vitro by inhibiting VEGR2-mediated PI3K/AKT and FAK signaling pathways. Cell Physiol Biochem 35: 1689-1705, 2015.

32. Seth P, Lin Y, Hanai J, Shivalingappa V, Duyao MP and Sukhatme VP: Magic roundabout, a tumor endothelial marker: Expression and signaling. Biochem Biophys Res Commun 332: 533-541, 2005.

33. Suchting S, Heal P, Tahtis K, Stewart LM and Bicknell R: Soluble Robo4 receptor inhibits in vivo angiogenesis and endothelial cell migration. FASEB J 19: 121-123, 2005.

34. Liu D, Hou J, Hu X, Wang X, Xiao Y, Mou Y and De Leon H: Neuronal chemorepellent Slit2 inhibits vascular smooth muscle cell migration by suppressing small GTPase Racl activation. Circ Res 98: 480-489, 2006.

35. Wang YS, Eichler W, Friedrichs U, Yafai Y, Hoffmann S, Yasukawa T, Hui YN and Wiedemann P: Impact of endostatin on bFGF-induced proliferation, migration, and matrix metalloproteinase-2 expression/secretion of bovine choroidal endothelial cells. Curr Eye Res 30: 479-489, 2005.
36. Schneeweis C, Gräfe M, Bungenstock A, Spencer-Hänsch C, Fleck E and Goetze S: Chronic CRP-exposure inhibits VEGF-induced endothelial cell migration. J Atheroscler Thromb 17: 203-212, 2010.

37. Huang L, Xu Y, Yu W, Li Y, Chu L, Dong J and Li X: Effect of Robol on retinal pigment epithelial cells and experimental proliferative vitreoretinopathy. Invest Ophthalmol Vis Sci 51: 3193-3204, 2010.

38. Park KW, Morrison CM, Sorensen LK, Jones CA, Rao Y, Chien CB, Wu JY, Urness LD and Li DY: Robo4 is a vascular-specific receptor that inhibits endothelial migration. Dev Biol 261: 251-267, 2003.

39. Huminiecki L, Gorn M, Suchting S, Poulsom R and Bicknell R: Magic roundabout is a new member of the roundabout receptor family that is endothelial specific and expressed at sites of active angiogenesis. Genomics 79: 547-552, 2002.

40. Li S, Huang L, Sun Y, Bai Y, Yang F, Yu W, Li F, Zhang Q, Wang B, Geng JG and Li X: Slit2 promotes angiogenic activity via the Robo1-VEGFR2-ERK1/2 pathway in both in vivo and in vitro studies. Invest Ophthalmol Vis Sci 56: 5210-5217, 2015.

41. Han S, Kong YC, Sun B, Han QH, Chen Y and Wang YC: microRNA-218 inhibits oxygen-induced retinal neovascularization via reducing the expression of roundabout 1 . Chin Med J (Engl) 129: 709-715, 2016

42. Chen GX, Wang HY, Liu T, Yang MT, Zhou ZY and Feng G: Myocardial Slit2/Robo4 expression and impact of exogenous Slit 2 on proliferation and migration of cardiac microvascular endothelial cells. Zhonghua Xin Xue Guan Bing Za Zhi 41: 1034-1039, 2013 (In Chinese).

43. Yu J, Zhang X, Kuzontkoski PM, Jiang S, Zhu W, Li DY and Groopman JE: Slit2N and Robo4 regulate lymphangiogenesis through the VEGF-C/VEGFR-3 pathway. Cell Commun Signal 12: 25, 2014.

44. Han X and Zhang MC: Potential anti-angiogenic role of Slit2 in corneal neovascularization. Exp Eye Res 90: 742-749, 2010.

45. Enomoto S, Mitsui K, Kawamura T, Iwanari H, Daigo K, Horiuchi K, Minami T, Kodama T and Hamakubo T: Suppression of Slit2/Robol mediated HUVEC migration by Robo4. Biochem Biophys Res Commun 469: 797-802, 2016.

46. Rama N, Dubrac A, Mathivet T, Ní Chárthaigh RA, Genet G, Cristofaro B, Pibouin-Fragner L, Ma L, Eichmann A and Chédotal A: Slit2 signaling through Robo1 and Robo2 is required for retinal neovascularization. Nat Med 21: 483-491, 2015.

47. Gavard J and Gutkind JS: VEGF controls endothelial-cell permeability by promoting the beta-arrestin-dependent endocytosis of VE-cadherin. Nat Cell Biol 8: 1223-1234, 2006.

48. Garrett TA, Van Buul JD and Burridge K: VEGF-induced Rac1 activation in endothelial cells is regulated by the guanine nucleotide exchange factor Vav2. Exp Cell Res 313: 3285-3297, 2007. International (CC BY-NC-ND 4.0) License. 